\title{
LA AUTORIDAD, EL PÁNICO Y LA BELIGERANCIA. POLITICAS DE ORDEN PÚBLICO Y VIOLENCIA POLÍTICA EN LA ESPAÑA DEL FRENTE POPULAR'
}

\author{
The authority, the panic, and the belligerency. \\ Public order policies and political violence \\ in Spain during the Popular Front
}

\author{
SERGIO VAQUERO MARTÍNEZ \\ Universidad Complutense de Madrid \\ servaque@ucm.es
}

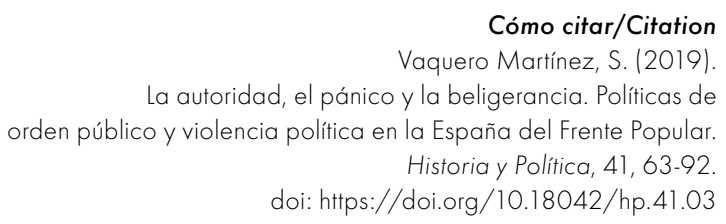

(Recepción: 08/05/2018; Evaluación: 15/06/2018; Aceptación: 07/11/2018; Publicación: 13/05/2019)

\section{Resumen}

El presente artículo analiza la relación entre las políticas de orden público y el incremento de la violencia política que tuvo lugar en España entre febrero y julio de

Esta investigación está financiada por un contrato para la formación del profesorado universitario del Ministerio de Educación, Cultura y Deporte; y se enmarca en el proyecto «La violencia política de 1936 y el 18 de julio como punto de ruptura. Un análisis micro» (HAR2015-65115-P), sufragado por el Ministerio de Economía y Competitividad y el Fondo Europeo de Desarrollo Regional. Una primera versión del texto fue presentada en el XIII Congreso de la Asociación de Historia Contemporánea, celebrado en la Universidad de Castilla-La Mancha en septiembre de 2016. Agradezco a Fernando del Rey, Manuel Álvarez Tardío, Ricardo Robledo y José Luis Ledesma todos sus valiosos comentarios. 
1936. El restablecimiento inicial de una política reformista y menos represiva paradójicamente estimuló el desarrollo de cuatro catalizadores de la violencia: la deslegitimación gubernamental, la politización de la administración del orden público, la desautorización de los cuerpos policiales y la privatización del uso político de la fuerza. A partir de mayo, el Gobierno Casares intentó solucionar el problema intensificando la persecución del terrorismo falangista, desacelerando la republicanización de la Policía, restableciendo el principio de autoridad y recuperando el control de los resortes de orden público. Sin embargo, aunque estas medidas redujeron significativamente el número de víctimas mortales, la violencia política siguió siendo considerablemente elevada, los militares continuaron conspirando y el Estado no recuperó el monopolio de la coerción letal. Este periodo concluyó con el asesinato de Calvo Sotelo y la sublevación militar, que fue respaldada por al menos la mitad de las fuerzas policiales como una reacción no solo contra la grave situación del orden público, sino también contra unas políticas democratizadoras que habían socavado su autoridad y resquebrajado el monopolio estatal del ejercicio de la violencia.

\title{
Palabras clave
}

Segunda República; Frente Popular; orden público; violencia política.

\begin{abstract}
This article analyses the relationship between public order policies and the increase of political violence that took place in Spain between February and July 1936. The reestablishment of a reformist and less repressive policy paradoxically stimulated the development of four causal factors of violence: government delegitimisation, politicisation of the public order administration, de-authorisation of police forces, and privatisation of the political use of force. Since May, the Casares Government tried to solve the problem by intensifying the persecution of Falangist terrorism, decelerating the republicanisation of the police, reestablishing the principle of authority, and recovering the control of public order resources. Nevertheless, although these measures significantly reduced the number of mortal victims, the political violence remained considerably high, the military went on conspiring, and the State did not recover the monopoly of lethal coercion. This period concluded with Calvo Sotelo's murder and the military rebellion, which was supported at least by half of the police forces as a reaction not only against the dangerous situation of public order, but also against the democratising policies that had undermined their authority and the state monopoly of the use of violence.
\end{abstract}

\section{Keywords}

Second Republic; Popular Front; public order; political violence. 
I. INTRODUCCIÓN. II. LA DISCRETA ABSTENCIÓN DE LA AUTORIDAD. III. EL REMOLINO DE LAS CORRIENTES DE PÁNICO. IV. LA BELIGERANCIA ANTIFASCISTA DE SANTIAGO CASARES. V. CONCLUSIÓN. BIBLIOGRAFÍA.

\section{INTRODUCCIÓN}

La imagen de la época del Frente Popular como un periodo caracterizado principalmente por la violencia debe mucho al esfuerzo que hicieron las autoridades franquistas para legitimar la rebelión que les había llevado al poder. El Dictamen de la Comisión sobre ilegitimidad de poderes actuantes en 18 de Julio de 1936 atribuyó la responsabilidad del estallido de la guerra a los Gobiernos republicanos por haber permitido que los desórdenes alcanzaran niveles insostenibles. Joaquín Arrarás desarrolló este relato describiendo el periodo como una «ola de vandalismo», un "huracán anárquico» y una «riada revolucionaria» en la que los disturbios se propagaron como un «mal infeccioso» para dar cuerpo al "clima trágico» de aquella primavera, en expresión de Ricardo de la Cierva. Siguiendo este relato, ello se debió a la «inhibición» $\mathrm{y}$ «complacencia» de las autoridades ante aquella «marea de desmanes» protagonizada por las organizaciones obreras, cuyas intenciones revolucionarias les condujeron a atacar continuamente a las fuerzas coercitivas; así como a su sectarismo, dado que la represión solo afectó a unas derechas calificadas como «fascistas». Esta persecución culminó con el asesinato de Calvo Sotelo, cuyo responsable había sido el propio Casares por haberlo instigado supuestamente desde las Cortes y no haber adoptado medidas preventivas. Dicho magnicidio demostró el grado de barbarie alcanzado por la sociedad como consecuencia de la "política de exterminio» del Gobierno y la necesidad por puro «instinto de conservación» de un alzamiento que no solo no destruyó la democracia, dado que esta ya había sido asesinada por sus "guardianes», sino que vino a poner fin a una guerra pretendidamente en curso desde el 16 de febrero ${ }^{2}$.

El relato anterior fue rebatido con solvencia por hispanistas como Hugh Thomas, Raymond Carr o Pierre Broué. No obstante, estos historiadores mantuvieron esa lectura catastrofista y teleológica inspirada en el tópico de la

2 Estado español (1939): 65, 71 y 75; Arrarás (1968): 66, 123-124, 134-135, 205, 207, 295, 322 y 389-390, y Cierva (1967): 61, 471 y 606. 
«primavera trágica», mediante la cual la fase frentepopulista era concebida como un mero preludio o "pendiente» hacia una guerra inevitable causada por el fracaso del régimen. No es casualidad que Gabriel Jackson, en su estudio seminal sobre el periodo republicano, titulara el capítulo dedicado a esta etapa «Se avecina la guerra civil». Con todo, pese a la persistencia que este sesgo ha tenido en la historiografía, actualmente la mayoría de especialistas coinciden en defender el estudio de la República por su interés particular y en considerar que la guerra no era el único desenlace posible. Sin embargo, la discusión sobre la naturaleza y las causas de la violencia y la responsabilidad de los distintos actores sigue candente ${ }^{3}$.

Unos historiadores señalan al Estado como principal ejecutor de la violencia. Eduardo González Calleja lo explica mediante la persistencia de un concepto autoritario del orden público que anteponía la salvaguardia del poder gubernativo al ejercicio de las libertades cívicas. Ello se materializó, según Rafael Cruz, en unas políticas de «exclusión» mediante las cuales los gobernantes buscaban impedir las protestas colectivas de sus "enemigos», lo que confirió cierta «impunidad» a los cuerpos coercitivos e inclinó a los desafiantes a utilizar la violencia. Por este motivo, la mayoría de los asesinatos fueron obra de las instituciones coactivas, especialmente de la Guardia Civil, cuya cultura corporativa la hacía especialmente refractaria al uso de técnicas preventivas y proporcionadas de control policial. Esto se reflejó también no solo en sus connivencias con Falange, sino en una notable falta de lealtad hacia las autoridades que causó que estas perdieran el dominio de buena parte de los resortes represivos, algo que fue clave para el estallido de la rebelión. Desde esta perspectiva, además, el incremento de la movilización fue algo inherente al acceso del "pueblo» a la política y tuvo un carácter generalmente pacífico, constituyendo una manera de presionar al Gobierno para que cumpliera el programa del Frente Popular, en opinión de Francisco Sánchez Pérez. Por esta razón, Julián Casanova relativiza la conflictividad social del periodo en comparación con los bienios anteriores, mientras que otros especialistas recuerdan que había habido Gobiernos en el pasado que habían soportado niveles similares de violencia sin derrumbarse. Finalmente, estos historiadores destacan la «estrategia de la tensión» practicada por Falange y la "construcción social del miedo» acometida por unas derechas que no estaban siendo perseguidas, sino que pretendían dramatizar los desórdenes con el fin de preparar el terreno para la sublevación militar ${ }^{4}$.

Ledesma (2013): 317, y Jackson (2005): 202.

4 González Calleja (2014): 51-55, 282 y 319-320; Cruz (2006): 20, 41-42, 118, 159, 164, 166, 168 y 192; Gil Andrés (2000): 454; Sánchez Pérez (2016): 25; Casanova (2007): 62 y 163, y Martín Ramos (2015): 154. 
Una interpretación alternativa sugiere como clave de la violencia la existencia de una cultura política excluyente inspirada en una concepción patrimonial del régimen. Su materialización fueron unas políticas policiales partidistas, basadas en una indiscriminada persecución de Falange que afectó a otras organizaciones derechistas y la contemporización ante las acciones subversivas de las asociaciones del Frente Popular. Para Fernando del Rey, el origen del "cerco al mundo conservador» estuvo en la emergencia de un "poder bifronte» que opuso a los gobernadores civiles, la Guardia Civil y la Guardia de Asalto frente a los ayuntamientos, las comisiones gestoras y las guardias cívicas socialistas, que desempeñaban ilegalmente funciones parapoliciales. Sobre las fuerzas coactivas, subraya su rol como «legítimas depositarias de la función de preservar el orden público" y sostiene que, pese a la continuidad de sus rigurosos métodos de actuación y su perfil castrense, normalmente se limitaron a cumplir órdenes y no abusaron del uso de la fuerza, salvando algunos casos excepcionales, como Arnedo y Casas Viejas. De ahí que sostenga, como Manuel Álvarez Tardío y Roberto Villa, que el origen del problema no hay que buscarlo en sus intervenciones sino en la gravedad de los desórdenes promovidos por ciertas organizaciones sociopolíticas. Por esta razón, estos autores insisten en que la conflictividad no debería considerarse un artificio propagandístico de las derechas. Por otro lado, Gabriele Ranzato defiende que los dirigentes toleraron y recurrieron ocasionalmente a las milicias marxistas, posibilitando cierto control de la Policía por parte de la extrema izquierda. Asimismo, Stanley Payne acusa a los Gobiernos de introducir milicianos en la misma como delegados, igual que hizo Hitler con las SA y la Hilfspolizei 5 .

Podría decirse que la discusión respecto a la violencia política del periodo ha versado fundamentalmente sobre la intensidad alcanzada por dicho fenómeno, el talante más o menos represivo de los Gobiernos y la responsabilidad de las fuerzas estatales. Cuestiones que remiten a una materia que ha sido ignorada durante décadas por haber sido el tópico por antonomasia esgrimido por la literatura franquista para justificar la sublevación: el orden público. Consecuentemente, este artículo pretende analizar la relación existente entre las políticas de orden público y el incremento de la violencia política entre febrero y julio de 1936. La tesis defendida sostiene que el restablecimiento por parte de Azańa de una política reformista, civilista y más permisiva con la movilización izquierdista tuvo el paradójico efecto de potenciar ciertos factores que catalizaron la violencia. Posteriormente, Casares intentó remediarlo frenando la republicanización policial y retomando el control de los resortes

5 Álvarez y Villa (2010): 16 y 205-206; Del Rey (2008): 521-524 y 526-528; Del Rey (2007): 36-42; Ranzato (2008): 166-167 y 170-171, y Payne (2016): 130. 
de orden público y la calle. Mediante esta estrategia consiguió reducir el número de asesinatos, aunque no llegó a recuperar los niveles de los bienios anteriores, ni logró acabar con las actitudes conspirativas de los militares ni restituir el monopolio estatal de la violencia política letal. Por último, el repunte del pistolerismo que desembocó en el asesinato de Calvo Sotelo y, en última instancia, la sublevación de las fuerzas militares y policiales hicieron imposible que esta política terminara de dar sus frutos.

\section{LA DISCRETA ABSTENCIÓN DE LA AUTORIDAD}

La victoria electoral del Frente Popular el 16 de febrero colocó al presidente Manuel Portela Valladares en una difícil situación. Por un lado, las manifestaciones reclamando la liberación de presos y algunas reyertas amenazaban con perturbar gravemente el orden público. Por otro, las exigencias de José María Gil Robles y el general Franco — que ya había sondeado sin éxito al general Pozas, inspector general de la Guardia Civil- de que se mantuviera en el poder y cortara los desmanes declarando el estado de guerra demostraban la existencia de movimientos en el Ejército para preparar otra militarada. Ante esta tesitura, el político gallego transfirió precipitadamente sus poderes a Manuel Azaña, que se encontró como resultado con los «gobernadores civiles desaparecidos» y la gente «suelta por las calles». Poco después la muchedumbre empezó a congregarse en la Puerta del Sol y el director general de Seguridad, Vicente Santiago, se dispuso a sacar a los guardias de seguridad. No obstante, Azaña no solo se lo impidió, sino que consiguió que se disolvieran pacíficamente tras pronunciar unas palabras. Sin embargo, en el resto del país los desórdenes se extendieron rápidamente, destacando especialmente los disturbios anticlericales de Alicante, Huelva y Játiva, así como los motines carcelarios de Burgos, Cartagena, Chinchilla, San Miguel de los Reyes y Santońa, que dejaron no menos de cuarenta muertos esa semana ${ }^{6}$.

Para evitar salir a "motín por día», el dirigente alcalaíno solicitó por radio a la nación que correspondiera a sus "propósitos de pacificación» para que pudiera restablecer la libertad, la Constitución y el «espíritu republicano». Tras anunciar la restitución de los ayuntamientos populares y prometer el cumplimiento del programa del Frente Popular, el presidente pidió a sus votantes que no perturbaran la paz y no malograran la victoria por «motivos

6 Portela Valladares (1988): 175-196; Mera Costas (2015): 310-318; Azaña (2004): 933 y 938-940, y González Calleja (2015): 294. 
de impaciencia». A sus detractores, en cambio, les aseguró que no habría persecuciones si se mantenían dentro de la ley, que la "defensa de la República» solo afectaría a sus enemigos y que en ella cabía todo aquel que sintiera "amor a la patria, la disciplina y el respeto a la autoridad»?

Este discurso apaciguador y un tanto conservador fue acompañado por ciertas medidas. Además de preparar otra combinación de gobernadores civiles, Azaña consiguió que se aprobara la prometida amnistía de los delitos sociopolíticos y ordenó la readmisión de los obreros despedidos en octubre de 1934, así como un uso más moderado de la represión que benefició a las organizaciones frentepopulistas. Poco después, el ministro de Gobernación, Amós Salvador, suspendió las licencias de armas cortas y largas de cañón estriado en Madrid, disponiendo su revisión en toda España, y prorrogó treinta días el estado de alarma, una medida que se iría renovando hasta el estallido de la guerra ${ }^{8}$.

Las fuerzas policiales recibieron el resultado de las elecciones con inquietud. La revista Policía Gubernativa destacó el papel de los agentes en esa «batalla sin cuartel» en la que habían corrido «rumores inquietantes» que amenazaban con «turbar la paz» y recordó a los dirigentes que les debían parcialmente su triunfo por haberse mantenido neutrales y ecuánimes, como la «representación viva de la Ley». También garantizó la lealtad de la Policía, asegurando que su misión era «apoyar firme y resueltamente los resortes del mando», aunque advirtió que su respaldo aumentaría cuanto mayor fuera su «fuerza moral». iPresente...!, por su parte, celebró el resultado definiendo a los policías como hijos del pueblo y parte de ese «sufrido proletariado» que esperaba el reconocimiento de sus derechos, y pidió el "perdón magnánimo» de sus «hermanos de origen» por la represión del bienio anterior, argumentando que estaban obligados a cumplir órdenes?.

Con el objetivo de paliar la ansiedad de los agentes, el Gobierno restableció la Oficina de Información y Enlace en la Dirección General de Seguridad y calificó como "hechos de guerra" unos sucesos acaecidos en Jerez de la Frontera y Arcos en los que un guardia civil había sido asesinado. No obstante, la simpatía de las fuerzas estatales se vio resentida por una disposición que resquebrajaba el secular centralismo del sistema de orden público: la

Azaña (2004): 940, y Ahora, 21-2-1936, p. 4.

8 Gaceta de Madrid, 22-2-1936, 53, p. 1515; Gaceta de Madrid, 1-3-1936, 61, p. 1762; González Calleja (2014): 91; Gaceta de Madrid, 26-2-1936, 57, pp. 1615-1616; Gaceta de Madrid, 10-3-1936, 70, p. 1957, y Gaceta de Madrid, 17-3-1936, 77, p. 2132.

9 "La función policial en las elecciones», Policía Gubernativa, 20-2-1936, p. 1, y «La voluntad nacional», iPresente...!, 1-3-1936, pp. 1-2. 
derogación del decreto de suspensión de la Comisión Mixta. De esta manera, el Ejecutivo reactivaba el traspaso de los servicios policiales a la Generalitat de Cataluña, el cual había sido revertido en el bienio anterior. A ello había que sumar el traslado de numerosos jefes y oficiales por la mala relación que habían tenido con las organizaciones socialistas, incluidos diecisiete jefes de Comandancia de la Guardia Civil. Este recurso se empleó profusamente en marzo y acabó afectando a los tenientes coroneles de la mitad de las provincias españolas ${ }^{10}$.

La prensa corporativa recibió con agrado el mantenimiento del estado de alarma argumentando que no supondría ningún problema porque su deseo de respetar los derechos cívicos garantizaba la protección de las «personas decentes", aunque reconoció que no podía evitarse que sufrieran algunas molestias: «No se puede limpiar el trigo sin removerlo». Aunque esto quedó eclipsado por otras reformas que generaron mayor malestar. La más importante fue la amnistía, no solo porque liberó a los prisioneros procesados por los sucesos de Castilblanco y Asturias — donde la Guardia Civil había sufrido 86 muertos y 77 heridos y la Policía 70 y 74 -, sino porque fue seguida por la condena de un capitán llamado Nilo Tello a doce años de prisión por las brutalidades que había cometido en la represión de octubre, una sanción que no tenía precedentes en la historia del Instituto ${ }^{11}$.

El segundo elemento de discordia fue la republicanización, sobre todo después de que la prensa publicara unas declaraciones del nuevo director general de Seguridad, José Alonso Mallol, en las que había señalado cierta «tibieza republicana» entre la fuerza pública. La respuesta de sus revistas fue reivindicar que la Policía «no puede ni debe ser un organismo al servicio de tal o cual idea, porque entonces dejaría de ser un Cuerpo nacional, para convertirse en un instrumento o milicia de partido». A su entender, su misión era mantenerse leal al poder legítimo y constituir el principal baluarte de la República, ya que ese «virus político» no solo socavaba los «ligamentos de la disciplina», sino que adhería a la acción represiva una "pasión» adicional que generaba odio entre los ciudadanos. Por su parte, Investigación propuso además una «operación de higiene corporativa» que purgase a los ineptos, inmorales y traidores y que no excluyera a los agentes vinculados con ciertos partidos políticos. Esta publicación, cuyo lema era «Reorganización y republicanización», consideraba que en el primer bienio este proceso no había afectado realmente

10 Gaceta de Madrid, 27-2-1936, 58, p. 1652; Gaceta de Madrid, 1-3-1936, 61, p. 1761; Gaceta de Madrid, 5-3-1936, 65, p. 1844, y Rivas (1976): 103 y 142.

11 "La función del guardia de Seguridad y Asalto", ;Presente...!, 1-3-1936, p. 11; Blaney (2007): 54; González Calleja (2014): 233, y Ahora, 12-3-1936, p. 3. 
a la Policía y que los agentes más comprometidos habían sido perseguidos, por lo que presionó por una mayor profundización para que los policías obtuvieran más derechos laborales ${ }^{12}$.

Por otro lado, aunque el incremento de la movilización colectiva tuvo una naturaleza mayoritariamente pacífica, conllevó también un crecimiento de las formas de protesta violentas. Como escribió Azaña: "Creo que van más de doscientos muertos y heridos desde que se formó el Gobierno, y he perdido la cuenta de las poblaciones en que han quemado iglesias y conventos». Este fenómeno generó un intenso debate mediático sobre el problema del orden público. El periódico católico El Debate condenó la «dictadura» de la calle ejercida por los "partidos revolucionarios» y denunció al Gobierno por no garantizar los derechos cívicos ni el uso de la vía pública por parte de todos y por no restablecer el «imperio de la ley» mediante el empleo de la fuerza, añadiendo que «la seguridad de la calle es la expresión y el símbolo de la libertad ciudadana». El Socialista defendió la política de «discreta abstención» aplicada por Azaña, acusó a las derechas de desacreditarlo presentándolo como un gobernante «débil» o «sanguinario» y pidió a sus lectores que no cayeran en las provocaciones fascistas usando una violencia que, por otro lado, no dejaba de justificar recordando la represión de octubre. En cambio, el diario liberal Ahora recomendó serenidad para que no se esparcieran rumores ni se exageraran ciertos sucesos y exigió al Gobierno que acabara con la «indisciplina en las calles» e impusiera la «ley y la autoridad», sosteniendo que "en las democracias la masa se moviliza en los comicios" solamente. De manera similar, El Sol le pidió al presidente que no abandonase la «suprema prerrogativa» de imponer el «principio de autoridad», cuyo depósito no podía quedar «en medio de la calle en motín y a merced de turbas en insurrección $»^{13}$.

Este cruce de opiniones venía a plantear al Gobierno el «dilema del orden público» teorizado por Diego Palacios. El principal reto del Ejecutivo consistía en hallar un modo de reducir simultáneamente los costes políticos de la represión y los derivados de la inhibición, los cuales implicaban una pérdida de legitimidad ante diferentes sectores del espectro político y cuya solución

12 "¿Tibieza republicana?...», Investigación, 29-2-1936, pp. 2-3; "Neutralidad precisa», ¡Presente...!, 15-3-1936, p. 2, y «¡Justicia, y nada más que justicia!», Investigación, 29-2-1936, pp. 4-5.

13 Rivas Cherif (1979): 665-666; «La calle debe ser del Gobierno», El Debate, 12-31936, p. 1; «La provocación y las violencias», El Socialista, 12-3-1936, p. 1; «El orden material y el moral», Ahora, 13-3-1936, p. 3, y «El principio de autoridad», El Sol, 13-3-1936, p. 1. 
pasaba por la institucionalización de la acción colectiva y la adopción de tácticas y útiles no letales de control policial de la protesta ${ }^{14}$.

El ambiente se enrarecería todavía más tras el atentado perpetrado el día 12 por cuatro pistoleros falangistas contra Luis Jiménez de Asúa en el que murió su escolta, el agente de investigación Jesús Gisbert. Su entierro se convirtió en una manifestación antifascista formada por 80000 personas que desembocó en graves disturbios. Concretamente, el Café del Norte sufrió un saqueo y fueron incendiados la redacción de La Nación y los templos de San Luis y San Ignacio, donde murieron dos bomberos; y, además, hubo diversos tiroteos, uno de los cuales se cobró la vida de un guardia de seguridad. La reacción del Gobierno fue ordenar la detención de la junta directiva de Falange, incluido José Antonio Primo de Rivera. Sin embargo, esta medida generó una oleada de atentados, enfrentamientos con la fuerza pública, asaltos de sedes de partidos y periódicos de derechas y disturbios anticlericales en otras ciudades — destacando Logroño, Valencia y Albacete-, que dejaron un total de 11 muertos y 24 heridos esa semana ${ }^{15}$.

La reacción policial al asesinato fue de profunda indignación. Sus revistas reclamaron «justicia inexorable» contra esos pistoleros que, «escudados en falsas ideologías políticas, las hacen banderín de sus asesinatos» y más respeto para los que «saben sacrificarse y morir en defensa de la sociedad, del orden y de la República». Sin embargo, su exigencia más importante era la de aplicar la ley "con mano firme» contra esos atentados que tantos «caídos en cumplimiento del deber» habían dejado: «iEs tan poco temido el rigor de las leyes, que ya cualquiera de esos forajidos cuenta por medias docenas los asesinatos de funcionarios del Orden público». En palabras de uno de sus articulistas: «Basta ya de titubeos. Basta ya de flaquezas. Barramos entre todos esa inmundicia humana», esa «larva social, cuyo virus se va extendiendo demasiado» ${ }^{16}$.

Esta situación socavó la confianza de la fuerza pública en la prometida reorganización, la cual también era defendida por la Guardia Civil —aunque con mucha menor intensidad - porque no quería perder su preponderancia en el aparato policial «víctima de la inexorable ley biológica de selección». Investigación escribió que las reformas olían a "puchero de enfermo" y que ya no era necesario «republicanizar la Policía», cuya lealtad había demostrado tanto en la Sanjurjada como en Asturias, sino dotar «a la República de la

14 Palacios Cerezales (2011b): 250-251.

15 González Calleja (2014): 277-279.

16 "Otra víctima de una campaña cobarde y ruin», Policía Gubernativa, 17-3-1936, p. 2; «Letras de luto», Investigación, 19-3-1932, pp. 1-2, y "Bajo el plomo asesino», iPresente...!, 15-2-1936, pp. 12-13. 
Policía que necesita». Dicha desconfianza les condujo a plantear reivindicaciones cada vez más ambiciosas: reserva del $50 \%$ de las plazas de oficiales para las clases del Cuerpo de Seguridad, cobro de quinquenios, reducción de la edad de jubilación, asistencia en hospitales militares y aumento de dietas e indemnizaciones, entre otras ${ }^{17}$.

La disposición que generó mayor oposición en las fuerzas coercitivas fue la creación de la situación de «disponible forzoso», mediante la cual el Gobierno pretendía cesar a los agentes sospechosos de tener connivencias con la extrema derecha. Esta medida se combinó con otra que dispuso que todas las vacantes en los destinos de elección del Ejército se cubrieran por libre designación del ministro de Guerra, para asegurar la obediencia de las jefaturas más importantes. Por otro lado, el restablecimiento del Servicio de Identificación en la DGS fue muy bien recibido por las revistas policiacas. Por último, hubo un cambio muy significativo en la protección de cargos públicos: las escoltas pasaron a estar desempeñadas por un agente de investigación y dos guardias de Seguridad y Asalto en lugar de por dos agentes, razón por la cual se creó en este cuerpo el Servicio de Vigilancias Políticas ${ }^{18}$.

\section{EL REMOLINO DE LAS CORRIENTES DE PÁNICO}

El retorno de las izquierdas al poder había alterado la estructura de oportunidades políticas, cuyas principales dimensiones son la apertura del sistema político institucionalizado, la estabilidad de las coaliciones y la presencia de aliados entre las élites políticas, y la capacidad y propensión del Estado en lo relativo al ejercicio de la represión. A los Gobiernos el vuelco electoral les había proporcionado oportunidades diferentes en comparación con el primer bienio debido a la radicalización tanto del ala caballerista del PSOE como del sector gilroblista de la CEDA, en perjuicio de las alternativas representadas por Prieto y Giménez Fernández, más comprometidas con la salvaguarda de las instituciones republicanas. Esto coincidiría con la convocatoria de tres elecciones durante este periodo: las municipales, la repetición

17 "Charla entre dos amigos», Revista Técnica de la Guardia Civil, marzo de 1936, pp. 146147; «¿Reformas?», Investigación, 19-3-1936, p. 7; «La política y la policía», Investigación, 19-3-1936, pp. 9-10; «Aspiraciones del Cuerpo de Seguridad», ;Presente...!, 1-4-1936, p. 11, y «Aspiraciones del Cuerpo de Seguridad», iPresente...!, 15-4-1936, p. 5.

18 Gaceta de Madrid, 24-3-1936, 84, pp. 2326-2327; Gaceta de Madrid, 27-3-1936, 87, p. 2436; Gaceta de Madrid, 28-3-1936, 88, pp. 2469-2470, y AHN, Causa General, Leg. 1560, Exp. 23. 
de las generales y las de compromisarios para elegir al presidente de la República. El resultado fue una formidable apertura del marco de oportunidades que causó un aumento sin precedentes de la incertidumbre política y, consecuentemente, de la acción colectiva, al constituir aquella una de sus principales fuentes de poder, como indica Sidney Tarrow. El problema fue que los Gobiernos fueron incapaces de canalizar este crecimiento de la movilización a través de unas instituciones ya bastante deslegitimadas por el modo en el que se había efectuado la sustitución de los ayuntamientos, la anulación de las actas de Granada y Cuenca y la destitución de Alcalá Zamora, algo que a la postre les obligaría a suspender los comicios locales poco después de haber sido convocados ${ }^{19}$.

Aunque la "política de enfrentamiento" propia de la calle, en términos de Rafael Cruz, seguiría acaparando la atención de la opinión pública, la reapertura de las Cortes devolvió cierta importancia a la política institucional. El 3 de abril Azaña presentó a su Gobierno, a través de sus representantes, como el único ejecutor de la política del Frente Popular y culpó del «atasco de la República» a la falta de compenetración entre su «autoridad moral» y su «poder legal», por un lado, y el apoyo y la confianza del pueblo, por otro. Posteriormente diferenció dos tipos de desórdenes: las «agresiones al régimen y al Gobierno" y las «indisciplinas de masas» no encuadradas en organizaciones políticas y, tras justificar el aumento de los disturbios y la «mengua de la autoridad" gubernativa que provocaba recordando la represión y el hambre sufridos por las masas durante el segundo bienio, condenó su "explotación política" y proclamó su intención de hallar la «manera de reprimirlos y, sobre todo, de impedirlos». A continuación, denunció un «modo de agredir a la política republicana» consistente en el cultivo de dos «corrientes de pánico» que formaban un auténtico «remolino»: a la derecha unos aventaban el miedo a la revolución y afirmaban que cualquier día España amanecería "constituida en soviet», con el objetivo de preparar el ambiente para que triunfara una rebelión militar; a la izquierda otros hacían algo semejante en sentido inverso, invocando el peligro constante de un golpe fascista, lo que irónicamente servía a los intereses de los primeros. Para concluir, el presidente defendió una política de seguridad menos represiva proclamando su negativa a vocear «bravatas estentóreas» o "gobernar España con una tranca», aunque puntualizando que no daría ninguna razón a aquellos que se salieran de la ley ${ }^{20}$.

Esta actitud más permisiva conllevaba que los gobernantes ordenaran el acuartelamiento de la fuerza pública ante las protestas del Frente Popular para

19 McAdam (1999): 54-55; Tarrow (1997): 183, y Gaceta de Madrid, 5-4-1936, 96, p. 163.

20 Cruz (2008): 8, y Diario de Sesiones de Cortes, 3-4-1936, 14, pp. 221-225. 
evitar que causaran víctimas, lo que generaba un importante rechazo entre los policías. Ante estas situaciones, sus revistas recomendaban a los guardias que reprimieran todos los desórdenes aunque alguna "autoridad incompetente» les censurase, porque así lo indicaba la ley, procurando «distinguir estos hechos tumultuarios y agresivos de aquellas manifestaciones pacíficas» que podían estar autorizadas y que no debían ser disueltas sin una orden. A su entender, «la autoridad que ordena retirar la fuerza pública de la calle comete un acto arbitrario en desprestigio del poder público; porque si tiene confianza en los manifestantes, ¿qué estorbo son las fuerzas? Y si no tiene confianza, es que hipoteca la tranquilidad pública». Este posicionamiento los llevaba a condenar también la conducta de esos "Gobernadores jóvenes, ayunos de toda experiencia, para quienes los guardias han sido soldaditos de plomo", arguyendo que sus decisiones hacían peligrar tanto el mantenimiento del orden como sus propias vidas ${ }^{21}$.

Dicha inhibición redujo sustancialmente la autoridad de los policías, lo que provocó no solo que sus intervenciones fueran más letales debido al aumento de la desobediencia de los desafiantes y la animadversión de los propios agentes, sino que las reformas policiales no llegaran a consolidarse, como apunta Palacios. Y es que, aunque la mayoría de los historiadores han tendido a infravalorar estas transformaciones aludiendo a su carácter tímido e insuficiente, Blaney ha demostrado que los avances habidos durante el periodo republicano fueron lo suficientemente significativos como para suponer un cambio respecto a las políticas policiales de la monarquía, a pesar de que el proceso de democratización quedara lejos de completarse ${ }^{22}$.

En su declaración en Cortes del día 15, Azaña prometió una «ley complementaria de amnistía» que incluyera otros delitos demandados por sus socios del Frente Popular. Asimismo, anticipó la depuración de los «abusos ilegales» cometidos por las fuerzas estatales en octubre, aunque también defendió la tesis de la individualización de las responsabilidades para evitar que la culpa se expandiese "como una mancha de aceite» sobre las corporaciones militares y policiales, desmarcándose así de la postura de buena parte de la izquierda obrera. Después propugnó su propósito de desarraigar del «carácter español» la «apelación cotidiana a la violencia física» y de lograr que "los españoles dejen de fusilarse los unos a los otros», argumentando que él no había venido a «presidir una guerra civil» sino más bien a evitarla. Seguidamente, continuó

21 «Carta de mi amigo», ¡Presente...!, 15-4-1936, p. 6, y «¿Sistema o conductas?», jPresente...!, 1-4-1936, pp. 1-2.

22 Palacios Cerezales (2011a): 644-645; González Calleja (2014): 55, y Blaney (2012): 113. 
haciendo gala de su calma y pidió a sus aliados que no sumaran «el tornavoz y el resonador de su propia alarma» al objetivo "perturbador y alarmista» de los elementos derechistas que causaban los desórdenes, los cuales, además, eran normalmente insignificantes. Para concluir, el presidente garantizó que para defender la República le bastaba con recurrir a las «instituciones normales del Estado", aunque aseguró estar convencido de que, en caso de emergencia, las Cortes no le regatearían poderes de carácter excepcional ${ }^{23}$.

La oposición continuó con la amplificación del ya de por sí grave problema del orden público, describiéndolo en términos anárquicos como la antesala de una revolución comunista. Calvo Sotelo replicó que en la calle la "garantía de la vida» era inexistente y que había multitudes uniformadas que daban vivas contra la patria, leyendo para demostrarlo una relación de todos los disturbios y las víctimas que había habido desde el 16 de febrero. Luego criticó la política de «desorden público, por condescendencia o por inhibición», de Azaña, acusándole de dar por supuesto que habría desmanes y de no intervenir para cortarlos, y también de no aplicar medidas que protegieran a las instituciones coercitivas de todo "conato de comunización», especialmente cuando las fuerzas del Frente Popular tenían el propósito de disolverlas. Por su parte, Gil Robles negó la tesis de los «agentes provocadores» como origen de los desórdenes y denunció que las derechas estaban sufriendo una "persecución implacable» que hacía germinar la «idea de la violencia» entre sus votantes y que, de seguir así, se vería obligado a darles la razón diciéndoles que «dentro de la legalidad no tenéis protección», aunque también añadió que era "preferible saber morir en la calle a ser atropellado por cobardía». Por su parte, Juan Ventosa le pidió al Gobierno que restableciera el «principio de autoridad» y reforzara la «satisfacción moral interior» de las fuerzas del orden. A continuación, el socialista Rodolfo Llopis insistió en el argumento de la «irritación» de las masas por la violencia padecida durante el «bienio negro» y afirmó que todos los actos anticlericales habían sido respuestas a provocaciones de los grupos contrarrevolucionarios, mientras que José Díaz acusó a la oposición de intentar desviar la atención de las responsabilidades por los "cinco mil muertos de Asturias» y amenazó de muerte a Gil Robles, diciéndole que si se cumplía la «justicia del pueblo" moriría "con los zapatos puestos». Finalmente, Antonio Alonso Ríos afirmó que tanto la Administración como el «espíritu» con el que se aplicaban las leyes eran monárquicos, lo que hacía urgente la republicanización de unas fuerzas policiales a las que acusaba de proteger a los pistoleros falangistas ${ }^{24}$.

23 Diario de Sesiones de Cortes, 15-4-1936, 17, pp. 283-284 y 288-289.

24 Prada Rodríguez (2011): 135; Diario de Sesiones de Cortes, 15-4-1936, 17, pp. 290 292, 295-296, 299-300, 304-311 y 315, y Gil Robles (2006): 701. 
Al día siguiente, Azaña respondió que el origen del problema no estaba en la proliferación de las protestas, sino en la «anarquía del propio Estado» que había tenido lugar en el segundo bienio, ya que la abolición de la Constitución y la responsabilidad, así como la «sanguinaria opresión» del pueblo, habían provocado que los Gobiernos perdieran su confianza. También destacó lo difícil que era gobernar debido a la coexistencia de «manifestaciones de progreso» que estaban protagonizadas por las clases proletarias y que eran comparables a las del resto de democracias europeas, y de «manifestaciones de atraso y casi de barbarie que parecen propias de un país del siglo XII». Después acusó a Gil Robles de incitar al uso de la violencia y condenó los incendios anticlericales por violentos e inútiles, aseverando que nadie podía dudar de «los desvelos del Gobierno por impedirlos o por reprimirlos». Seguidamente, el presidente proclamó que la República no corría peligro por los desórdenes y que para contenerlos «no hace falta cubrirse la frente de ceniza ni apelar a procedimientos extraordinarios, que son por lo común contraproducentes». Más tarde, anunció que había efectuado cambios en la Administración para evitar nuevos errores de funcionamiento y aseguró que estaba desarrollándose una «operación quirúrgica» entre el funcionariado debido a que había algunas personas «infiltradas» que, «sin faltar manifiestamente a su deber, tienen ese desmayo que nace de no comulgar en las mismas convicciones políticas que el Gobierno, que el régimen vigente». En último lugar, Azaña defendió que había que "proporcionar la represión» a la «magnitud del delito que se persigue» porque todo «lo demás es barbarie», así como «distinguir entre el orden público real y efectivo y la explotación política del desorden", destacando además que la mayoría de los choques se habían producido por "manifestaciones hostiles o provocativas de grupo a grupo»"

La réplica corrió nuevamente a cargo de Calvo Sotelo, que denunció que el "principio de autoridad" estaba "por el suelo, arrastrado de una manera incomprensible, manchándose de sangre y de lodo»; y reclamó «una autoridad fuerte, dispuesta a impedir que se sigan sembrando lutos y sangre por las calles» para que "no pueda el comunismo realizar la labor de zapa, de poda y de conquista» de las instituciones armadas. El político gallego condenó también el «inhibido escepticismo» del Gobierno ante unos desmanes «orgánicos y sistemáticos» que, a su juicio, estaban generando un clima favorable para la proliferación de atentados contra los agentes del orden. En consecuencia, Augusto Barcia respondió que la defensa de las fuerzas coercitivas era competencia del Ejecutivo y acusó a Calvo Sotelo de adularlas para intentar socavar su lealtad al régimen. Ventosa, por otro lado, insistió en que el poder público debía retener el «monopolio exclusivo de la autoridad» y actuar, tal vez no de

25 Diario de Sesiones de Cortes, 16-4-1936, 18, pp. 339 y 341-345. 
manera «bárbara y violenta» pero sí eficaz, para mantener el orden. Finalmente, el debate concluyó con la aprobación por 196 votos contra 78 de una proposición de confianza en el Gobierno ${ }^{26}$.

El tono de la oposición se había recrudecido a causa de los sucesos del entierro del alférez de la Benemérita Anastasio de los Reyes. Este oficial había sido tiroteado por unos sujetos a los que había reprendido por haber voceado insultos contra la Guardia Civil durante el desfile del aniversario de la República. Para evitar disturbios el Gobierno había ordenado trasladar su cadáver de noche y censurado la esquela del $A B C$, pero algunos miembros del Instituto liderados por el teniente coronel Florentino González Vallés robaron el cuerpo y convirtieron su funeral en una manifestación integrada por miles de guardias civiles, militares, policías, políticos y simpatizantes de partidos de derechas — sobre todo falangistas - incluidos Gil Robles, Honorio Maura y Calvo Sotelo. Durante la accidentada marcha hubo numerosos tiroteos y agresiones, un intento de asalto al Congreso y diversas cargas de la Guardia de Asalto, la más violenta de las cuales fue dirigida por el teniente José del Castillo. El resultado fueron seis muertos, entre los que destacó Andrés Sáenz Heredia, pariente de José Antonio Primo de Rivera ${ }^{27}$.

Como respuesta, el Gobierno encarceló a varios jefes y oficiales del Instituto; trasladó a 23 comandantes, 46 capitanes, 40 tenientes, 38 alféreces y a todo el $14 .^{\circ}$ Tercio; y acordó la ilegalización y disolución de todas las ligas y asociaciones fascistas. No obstante, lo más impactante fue un proyecto de ley —aprobado el día 23 - que privaba a los militares acogidos a las leyes de retiros de su derecho a percibir los haberes pasivos y a llevar uniforme cuando pertenecieran a organizaciones ilegales o participasen en acciones contrarias al orden público o al régimen republicano. Por otro lado, el Ejecutivo estimuló la republicanización de la Policía permitiendo ostentar un distintivo a los agentes premiados con la Corbata de la Orden de la República y segregando los servicios del Ministerio de Obras Públicas del Parque Móvil de los Ministerios Civiles, Vigilancia y Seguridad. Pero estas concesiones quedaron nuevamente ensombrecidas por la anulación de las disposiciones emitidas como consecuencia de la ley de 2 de enero de 1935, mediante la cual se habían restituido al Estado los servicios de orden público traspasados a la Generalitat, y el restablecimiento de la Junta de Seguridad encargada de coordinar la transferencia de dichas competencias ${ }^{28}$.

26 Diario de Sesiones de Cortes, 16-4-1936, 18, pp. 349-354.

27 González Calleja (2014): 299-300; Rivas (1976): 174-184, y Vidarte (1973): 90-91.

28 Gaceta de Madrid, 24-4-1936, 115, pp. 690-691; Gaceta de Madrid, 25-4-1936, 116, p. 739; Gaceta de Madrid, 26-4-1936, 117, pp. 786-787, y Gaceta de Madrid, 10-51936, 131, p. 1359. 
Este episodio produjo una reacción entre las revistas policiacas contra el peligro de la politización. Para empezar, condenaron el "confusionismo» presente en los funerales de Gisbert y Reyes, argumentando que el Gobierno tenía obligación de rendir tributo a las víctimas pero que resultaba inadmisible que determinados asistentes convirtiesen estos rituales en «manifestaciones políticas» levantando los puños y lanzando gritos contra las «turbas fascistas", o haciendo lo mismo en sentido contrario. En segundo lugar, respaldaron las medidas de disolución de las «milicias extremistas», argumentando que una «República ha de ser un pueblo; no puede ser una tribu ni una kábila». También insistieron en la necesidad de recuperar esa «armadura» llamada autoridad que permitía a los policías ingleses patrullar sin armas, para evitar que los agentes terminasen naufragando en ese «mar revuelto del pistolerismo». Por último, estas publicaciones criticaron el modo en el que se venía realizando la republicanización por haber causado la salida de policías leales y competentes, además del «trasiego constante de los mandos», y recomendaron a los guardias que no obedecieran a esos "frescos» afiliados a partidos izquierdistas que en "momentos de revuelta» se erigían ilegalmente como autoridades y pretendían darles órdenes, aprovechando el consentimiento o el retraimiento de los gobernadores ${ }^{29}$.

Aunque el principal motivo de insatisfacción entre las instituciones coercitivas seguía siendo la contemporización ordenada por las autoridades ante determinados tumultos. Entre el 3 y el 5 de mayo, a raíz del famoso bulo de los caramelos envenenados, una decena de edificios religiosos de Madrid fueron incendiados y seis religiosas y tres sacerdotes resultaron heridos durante unos disturbios, debido a la falta de medidas preventivas del Gobierno y a la tardía intervención de la Guardia de Asalto ${ }^{30}$.

Estos sucesos motivaron otra intervención de Calvo Sotelo en el Parlamento, en la que facilitó una nueva relación de episodios violentos entre el 1 de abril y el 4 de mayo, afirmando que había habido 47 muertos y 216 heridos. El diputado denunció la supuesta mediatización del «Estado oficial» por otro «subalterno, capcioso, muchas veces faccioso, por un Estado subversivo, integrado exclusivamente por el marxismo»; y aseguró que había "degradado su propia jerarquía insustituible y suprema, consintiendo la incrustación apendicular de organismos milicianos marxistas que suplen a las fuerzas del Estado» $\mathrm{y}$ «cachean, registran, detienen y ejercen facultades policíacas, amparados

29 «Confusionismo deplorable», ;Presente...! 1-5-1936, p. 6; "Hay que cortar el sacrificio estéril de vuestras vidas», Policía Gubernativa, 30-4-1936, p. 1; «Los que se van», ;Presente...!, 1-5-1936, p. 9, y "Carta de mi amigo», ;Presente...!, 1-5-1936, p. 10.

30 Álvarez y Villa (2013): 703 y 715. 
unas veces y suplantando otras a los gobernadores civiles». Casares acusó a las derechas de haber propalado el bulo y disculpó el «estado de exaltación, de histerismo, perfectamente enfermizo" de las multitudes. Luego informó de que unos fascistas habían utilizado balas «dum dum» en un tiroteo —enseńando dos ejemplares - y negó que pudiera acusársele de lenidad, sosteniendo que había ordenado que la fuerza pública interviniera "con energía y rapidez, pero sin la crueldad que vosotros hubierais deseado»; es decir, con «mesura» y «tranquilidad». Por último, tras asegurar que tenía las riendas de los resortes estatales «cada vez más en la mano, a pesar de los esfuerzos extraordinarios que se han hecho para romperlas», reconoció haber hallado "dislocamientos, desbordamientos si queréis, pero lealtad» en las fuerzas del Frente Popular; y replicó que eran los pistoleros de derechas los que trataban de «rebelarse contra el Estado, o bien crear un estado perpetuo de inquietud, que es mucho peor que una sublevación armada», lo que hacía más urgente su desarme ${ }^{31}$.

Ciertamente, esta incapacidad del Gobierno para controlar los ayuntamientos y las guardias cívicas socialistas no revelaba la existencia de una situación revolucionaria, como indica acertadamente González Calleja, pero sí un grave problema de gobernabilidad típico de los cambios de régimen que, como sostiene Diego Palacios, socavó la legitimidad de las autoridades políticas y obstaculizó sus proyectos democratizadores ${ }^{32}$.

\section{LA BELIGERANCIA ANTIFASCISTA DE SANTIAGO CASARES}

Después del fracasado intento de Azaña de incorporar a los socialistas en el gabinete ofreciéndole la presidencia a Prieto, Casares formó Gobierno el 13 de mayo, confiándole la cartera de Gobernación a Juan Moles. En su declaración ministerial, el presidente exhibió una retórica mucho más agresiva que buscaba capitalizar el discurso antifascista de la izquierda obrera para reforzar su colaboración y restablecer el control gubernativo sobre los resortes locales de orden público y la vía pública. El presidente proclamó que «contra el fascismo el Gobierno es beligerante» y prometió que la República «será respetada, y, si no, se hará temer», mediante la sustitución de una "táctica de defensa» por otra de «ataque a fondo» contra sus enemigos abiertos y «enmascarados», incluidos aquellos que la torpedeaban desde la "última covachuela» del Estado. Seguidamente, Casares solicitó el apoyo del Frente Popular para

31 Diario de Sesiones de Cortes, 6-5-1936, 25, pp. 620-625.

32 González Calleja (2014): 293, y Palacios Cerezales (2011a): 598. 
restablecer la paz, aunque insistió en que los únicos ejecutores de su política eran sus representantes y que no consentiría «huelgas políticas fuera de la ley», incautaciones ilegales ni «actos de violencia que sean un trágala al Gobierno» ${ }^{33}$.

En su intervención, Gil Robles culpó al Ejecutivo de haber despedazado el «ídolo de la democracia» y estar propagando el fascismo mediante la persecución de sus votantes, advirtiéndole que cuando sus aliados le rebasasen, ellos sabrían ponerse al lado de la autoridad para «dar a su Patria el sacrificio último que se puede pedir a un ciudadano». Por su parte, Calvo Sotelo defendió que el Gobierno no podía declararse beligerante ante ciertos ciudadanos sino «aplicar la ley inexorablemente». También denunció que el principio de autoridad se encontraba «a los pies de los enemigos jurados del Estado español» y que millones de españoles vivían «sojuzgados por unos déspotas rurales, monterillas de aldea, que cachean, registran, multan, se incautan de las fincas» y ejercen toda clase de funciones gubernativas con «total desprecio de la ley» y las órdenes de las autoridades, dando forma a una suerte de "régimen de taifas de la anarquía» inspirado en una especie de "cantonalismo asiático». Después exigió al presidente que fortaleciera la «satisfacción interior» de las corporaciones armadas y restableciera el principio de autoridad, pero no solo en los «cuartos de banderas», sino también en la calle. Para concluir, la mayoría presentó nuevamente una proposición de confianza en el Gobierno que fue aprobada por 217 votos contra 61, en la que se demandaba a los elementos del Frente Popular que dejaran de obstruir su labor ${ }^{34}$.

El discurso de Casares suscitó diversas respuestas en la prensa nacional. El periódico izquierdista La Libertad respaldó la «intervención enérgica e inflexible» del presidente y la definió como una «obligada acción gubernamental en defensa del régimen y del pueblo», aunque afirmó no comprender por qué consideró necesario decir que no gobernaría bajo coacciones «desde abajo». Más escéptico, Ahora destacó como «distintivo característico» del dirigente republicano su "decisión firme para mantener el orden público», pero le recordó que debía hacerlo como «norma general e inflexible», sin hacer distinciones según el «apellido político» de los ciudadanos. El diario monárquico $A B C$ condenó el «sectarismo» y el abandono de la «neutralidad obligada» del Ejecutivo frente a una doctrina "tan legal como cualquiera otra", y criticó que volviese a dejar para el futuro una actitud más enérgica contra las huelgas, las ocupaciones y las violencias cometidas por las bases frentepopulistas. Por su parte, el órgano del centrismo socialista apoyó el nuevo discurso, criticando que Casares no hiciera público quiénes estaban financiando a los agentes

33 Diario de Sesiones de Cortes, 19-5-1936, 29, pp. 692-694.

34 Ibid., pp. 697-698, 703-705 y 713. 
provocadores; subrayó la necesidad de terminar con los «miramientos» con las derechas; y apostó por aplicar una política «quirúrgica» sobre el Estado que neutralizara a aquellos que todavía sońaban con una militarada. Por último, Solidaridad Obrera tildó la declaración de "frase impresionista» y proclamó que «la verdadera y la única barrera de contención al fascismo» no venía formada por los gobiernos, sino por los sindicatos, lo que revelaba una creciente desconfianza en las políticas de seguridad del gabinete que no afectaba solo al anarcosindicalismo, sino también al socialismo y al comunismo ${ }^{35}$.

El cambio en la constitución del Ejecutivo supuso la implementación de una nueva política de recomposición del sistema de orden público y restablecimiento del principio de autoridad que, como señala Palacios, podía haber puesto las bases para la restauración del funcionamiento institucionalizado de la vida política y del protagonismo del Gobierno como ejecutor de las reformas. En primer lugar, Casares ordenó a los gobernadores civiles que observaran el procedimiento e informasen de los nombramientos de delegados gubernativos que hicieran para evitar la designación de miembros de las organizaciones de clase en lugar de policías de investigación, con el objetivo de recuperar el control de los mecanismos de mediación en los conflictos laborales. A continuación, modificó la Ley de Orden Público para agilizar las actuaciones policiales y judiciales contra los atentados, incluyendo entre los «actos contra el orden público» los delitos cometidos con armas o explosivos que tuvieran un móvil terrorista o una motivación política o social. Para concluir, el presidente intentó fortalecer la obediencia de las fuerzas coactivas mediante algunas concesiones, como la exención del pago de las cédulas personales a los alféreces ascendidos en diciembre, algo que sería criticado por la policía por no haber incluido a las clases y tropas del Cuerpo de Seguridad ${ }^{36}$.

Esta política sufrió un serio varapalo el 29 de mayo en Yeste, a raíz de la roturación ilegal de una finca. Unos vecinos que intentaban liberar a seis presos mientras eran trasladados por la Benemérita mataron a un guardia civil. Como respuesta, sus compañeros perpetraron una masacre que se cobró la

35 «La declaración ministerial es una ratificación de la política del Frente Popular», La Libertad, 20-5-1936, p. 1; «El debate político de ayer», Ahora, 20-5-1936, p. 3; "La declaración ministerial hecha por el presidente del Consejo da lugar a un discurso, de extraordinaria importancia doctrinal y política, del Sr. Calvo Sotelo», $A B C, 20-5-$ 1936, pp. 15-16; «Un ataque sin respuesta», El Socialista, 21-5-1936, p. 1, y «Contra el fascismo, el único beligerante es el proletariado", Solidaridad Obrera, 24-5-1931, p. 1.

36 Palacios Cerezales (2011a): 645-646; Gaceta de Madrid, 15-5-1936, 136, p. 1527; Gaceta de Madrid, 29-5-1936, 150, p. 1803, y «Exención de cédulas personales y otras reparaciones», ;Presente...!, 1-7-1936, p. 7. 
vida de diecisiete paisanos, aunque González Calleja destaca que previamente había habido un intento de negociación que revelaba un «tenue pero significativo cambio» en la actuación del Instituto. Este suceso demostró que la violencia no siempre se explicaba por la predisposición de la fuerza a ejercer la represión, sino que en ocasiones su propósito de no emplearla potenciaba una respuesta transgresora o violenta por parte de los protestantes, que a su vez provocaba una intervención policial más cruenta y desproporcionada ${ }^{37}$.

Durante el debate parlamentario, José Prat defendió que la agresión inicial había sido obra de los guardias civiles y que, pese a no haber tenido "gran volumen", había bastado para irritar a las masas. También destacó que los sucesos daban la impresión de que el Instituto seguía al servicio de la oligarquía. Por esta razón, el diputado del PSOE sostuvo que no podía haber impunidad para estos abusos porque la República era un «régimen de responsabilidad», aunque matizó que únicamente debían ser sancionados aquellos guardias que estuvieran implicados, desmarcándose así de una proposición que habían presentado los comunistas días antes para disolver la Benemérita, la cual había sido apoyada por los socialistas. Casares elogió que propusiera individualizar las responsabilidades y prometió castigar estos excesos. Además, agradeció a algunos diputados que hubieran investigado personalmente los hechos y anunció que había pedido al Tribunal Supremo que eligiese a un juez especial para que realizara una investigación oficial «sin distinción de fueros». Para terminar, el presidente defendió la lealtad de la Guardia Civil y aseguró que una comisión de jefes del Instituto le había pedido que se hiciera esta investigación "por el honor del Cuerpo»" ${ }^{38}$.

La Revista Técnica de la Guardia Civil, que había participado en el debate sobre las reformas policiales durante el primer bienio pero que desde 1934 apenas se pronunciaba al respecto, tampoco comentó estos sucesos, pero defendió con mayor insistencia sus aspiraciones profesionales: nivelar las plantillas de cabos y sargentos, ascender a más guardias segundos, aprobar un nuevo reglamento de régimen interior, dar a los guardias la consideración de sargentos y cobrar dietas como el resto de funcionarios. Por su parte, la Policía presionó contra la descentralización de competencias en Cataluña por los peligros que entrańaba el «sistema disgregador» y por miedo a que la proliferación de estatutos conllevase la aparición de numerosas fuerzas regionales, por lo que demandó que sus cuerpos siguieran dependiendo del Estado como la Benemérita. Pero el agravio más ultrajante era el intrusismo de las guardias

37 Requena Gallego (1983): 91-101, y González Calleja (2014): 126-127.

38 Diario de Sesiones de Cortes, 5-6-1936, 40, pp. 1188-1191 y 1195-1196, y Grandío (2011): 164 . 
cívicas, cuyos efectivos hacían registros con total impunidad, incluso en los domicilios de los policías, esgrimiendo su pertenencia a cualquier partido «extremista». Para evitarlo, sus revistas aconsejaron a los agentes que dispararan sobre los asaltantes, asegurando que estaban amparados por la ley, y exigieron al Ejecutivo que vigorizara el respeto a la Policía ${ }^{39}$.

A principios de junio Casares reforzó la vigilancia en los cuarteles, ordenó el desarme de las personas sin licencia, advirtió a los alcaldes que no consintieran cacheos ni registros ilegales de automóviles y prohibió las huelgas y los lock-outs no ajustados al procedimiento. El objetivo de estas disposiciones era recuperar la dirección efectiva de los medios coercitivos y reinstitucionalizar el uso de la fuerza. Además, el presidente prosiguió con la descentralización administrativa aprobando el acuerdo de la Junta de Seguridad, que establecía un plazo de dos meses para la devolución de los servicios policiales a la Generalitat y daba atribuciones a aquel organismo para sancionar a los policías que cometieran faltas graves o muy graves. Como compensación, el Gobierno restableció un decreto que obligaba a los tenientes del Ejército a pasar por las academias militares para poder ingresar en la Guardia Civil hasta que se restableciera la Academia Especial donde se formaban los oficiales del Instituto, cuya reapertura prometía abordar en el futuro. Asimismo, al Cuerpo de Seguridad le reconoció por fin el derecho a viajar gratis en los ferrocarriles del mismo modo que los guardias civiles. En último lugar, el gabinete dispuso el traslado de 62 efectivos del Instituto, algo que paradójicamente suponía un "ostensible reblandecimiento de posturas anteriores», según Fernando Rivas, debido a que la mayoría lo hacían por ascenso o voluntariedad, mientras que el resto eran disponibles forzosos que estaban siendo rehabilitados, como Antonio Reparaz, que había sido la mano derecha de Lisardo Doval en la represión de Asturias ${ }^{40}$.

El día 16 tuvo lugar otro debate parlamentario sobre el «estado de subversión» que reinaba en España. Gil Robles criticó la utilización abusiva del estado de excepción como un "instrumento de venganza» y leyó otro listado de «brotes anárquicos». Después denunció que España estaba "desgobernada» porque las autoridades no solo no obedecían, sino que consentían la

39 "Legítimas aspiraciones», Revista Técnica de la Guardia Civil, junio de 1936, p. 285; «El orden en Cataluña», Investigación, 19-5-1936, pp. 2-3; «Los servicios de orden público», Policía Española, 2-6-1936, p. 5, y «Carta de mi amigo», jPresente...!, 1-61936, p. 13.

40 Del Rey (2008): 546; Gaceta de Madrid, 3-6-1936, 155, p. 1988; Gaceta de Madrid, 4-6-1936, 156, pp. 2028-2029; Gaceta de Madrid, 16-6-1936, 168, p. 2386, y Rivas (1976): 324-325. 
usurpación de sus atribuciones, y proclamó que estaban "presenciando los funerales de la democracia» porque el Gobierno pretendía pedir plenos poderes para construir una «dictadura republicana». A continuación, Calvo Sotelo cargó contra aquella política de orden público «de desembolso, sin tasa ni freno", y contra un régimen de "desorden» que creía inspirado en una concepción degenerada de la democracia basada en el «fetichismo de la turbamulta». Luego condenó la indefensión del Ejército, que constituía la «más augusta encarnación» del principio de autoridad y la «columna vertebral» de la patria, y se atrevió a proclamar que estaría loco cualquier militar que «no estuviera dispuesto a sublevarse a favor de España y en contra de la anarquía». Consecuentemente, Casares le responsabilizó de cualquier militarada que pudiera haber y se presentó como el auténtico defensor de las corporaciones castrenses por haberles dado «algo más que palabras, apoyo moral y apoyo material». Para concluir, el presidente denunció la "fábrica de bulos» organizada por las derechas, replicando que al menos había una paz «relativa» que permitía a los ciudadanos circular por la calle, y negó que necesitase recursos extraordinarios para gobernar ${ }^{41}$.

La sesión continuó con las intervenciones de otros diputados de izquierdas. Pasionaria recordó los crímenes y las torturas de aquel «octubre glorioso, que significó la defensa instintiva del pueblo frente al peligro fascista», y aseguró que los «soldados del pueblo» sabrían contener a los "generalitos reaccionarios» que decidieran rebelarse. Joaquín Maurín, por su parte, criticó a Casares por no ser «verdaderamente beligerante contra el fascismo». Para terminar, Marcelino Domingo presentó otra moción de confianza insistiendo en la herencia recibida y defendiendo la nueva política policial: «Queremos autoridad, pero autoridad republicana; es decir, autoridad ágil, dinámica y legal; autoridad que nazca de las responsabilidades políticas que se han comprometido en pacto solemne» y que «nazca del impulso que el sufragio universal ha dado nuevamente a la República ${ }^{42}$.

Esta política tuvo sus efectos en el devenir de la violencia política. Según el exhaustivo estudio de González Calleja, en esta etapa hubo 384 muertos, que supusieron el 14,6\% de los 2629 que hubo durante toda la República. Lo más relevante fue el incremento que hubo en la tasa diaria de asesinatos, que pasó de 0,55 y 1,91 en los bienios primero y segundo, respectivamente, a 2,52 durante el Frente Popular. No obstante, este indicador experimentó un notable decrecimiento durante esta etapa: de 3,34 en el tercer Gobierno Azaña

41 Diario de Sesiones de Cortes, 16-6-1936, 45, pp. 1372-1377, 1384-1386, 1389 y 1391-1392.

42 Ibid., pp. 1394, 1396, 1399, 1404 y 1408-1411. 
—la segunda más alta del periodo tras el 7,43 alcanzado por el cuarto Gobierno Lerroux debido a la represión de octubre- a 2,26 durante el Gobierno Casares, aunque se quedó muy por encima de la media del periodo republicano, que era de 1,36 . Un segundo atributo de esta violencia fue su naturaleza "atomizada y desestructurada», fruto de la proliferación de atentados derivada de la reacción de los falangistas a la mayor firmeza de Casares y las represalias de las organizaciones obreras. Por último, el citado autor mantiene que las fuerzas estatales siguieron siendo las responsables del grueso de las muertes. Sin embargo, según sus propias cifras, mientras que en el primer bienio fueron responsables del $54,82 \%$ de los asesinatos y en el segundo del $61,8 \%$, durante el Frente Popular lo fueron del $29,16 \%$. Además, la presencia proporcional de los agentes del orden entre los victimarios descendió sustancialmente desde mayo, en buena medida porque, exceptuando los sucesos de Yeste y Bonete, habían dejado de provocar muertos durante las ocupaciones de tierras. Luego más que demostrar la tesis anterior, este dato evidencia no solo una mayor contención de los cuerpos coercitivos en el uso de la represión en comparación con el segundo bienio, sino también una diferencia fundamental respecto a las etapas anteriores: una pérdida coyuntural del monopolio de la violencia política letal por parte del Estado ${ }^{43}$.

A finales de mes, el Ejecutivo modificó nuevamente la Ley de Orden Público con el fin de reforzar los tribunales de urgencia para no tener que recurrir a los consejos de guerra, disponiendo que fueran los únicos órganos que conocieran los delitos contra el orden público y los de terrorismo, empleo de explosivos y tenencia ilícita de armas; asimismo, también se reforzaron los derechos y las garantías procesales de los encausados. Paralelamente, fue presentado un proyecto de ley de represión de actividades sociales ilícitas que pretendía refundir toda la legislación sobre terrorismo, posesión y uso de explosivos y tenencia ilegal de armas, aunque no llegó a ser aprobado. Además, en un intento de canalizar institucionalmente y despolitizar el creciente malestar en la Administración, el Gobierno constituyó una comisión interministerial que debía proponer un nuevo estatuto que regulase las condiciones, situaciones y obligaciones de los funcionarios; y vigilar el cumplimiento de los preceptos vigentes ${ }^{44}$.

La respuesta de la prensa policial fue bastante escéptica y reflejó la existencia de diferentes sensibilidades. pPresente...! criticó que el representante de Gobernación no fuera policía y pidió que los guardias de Seguridad y Asalto fueran militarizados para que obtuvieran las mismas ventajas que los guardias

43 González Calleja (2015): 88, 91-92, 150, 198, 271, 274, 276, 291 y 293.

44 Gaceta de Madrid, 23-6-1936, 175, p. 2580; Diario de Sesiones de Cortes, 23-6-1936, 49, apéndice 3. ${ }^{\circ}$, pp. 1-3, y Gaceta de Madrid, 21-6-1936, 173, pp. 2547-2548. 
civiles y dejaran de estar «a merced del capricho del mando», o que al menos se les concedieran los mismos derechos que al resto de funcionarios. En cambio, Investigación, en una línea más civilista, advirtió que la comisión era otro «amortiguador» ideado para mitigar las protestas policiales y retrasar la reorganización pendiente, y apostó por unificar la organización de los distintos cuerpos. Tal vez por ello Casares continuó satisfaciendo algunas de sus peticiones, por ejemplo, creando una Junta Central de Acuartelamiento encargada de la gestión, construcción y reparación de las casas cuarteles de la Guardia Civil o disponiendo la concesión de permisos de verano para los agentes de policía ${ }^{45}$.

Pero la ralentización de la depuración no fue suficiente para contener el malestar de sus revistas. La principal crítica de este "falso y nuevo concepto» de la republicanización era que permitía que los agentes más inmorales y revolucionarios cuestionaran la lealtad de aquellos otros que solo cumplían con su deber. Por esta razón, propusieron que se basara en el axioma de que «democracia es humanizar los sistemas, primero, y adaptar las personas después»; $y$, además, condenaron con dureza las iniciativas depuradoras de los sectores más politizados de la Policía: «¿Qué rabia os debe causar no poder decir de mí que soy "fascista"!», escribió un articulista que presumía de haber formado él solo un "contra comité». También reprocharon al pueblo su falta de respeto hacia la autoridad, su tendencia a apoyar instintivamente al delincuente y el «hermetismo» y la "mala fe» que demostraba cuando demandaban su cooperación. Por su parte, jPresente...! insistió en su defensa de la militarización inspirándose en el modelo de la Guardia Civil, argumentando que su organización y su reglamento eran "perfectos», que la antigua dependencia parcial del Ministerio de Guerra la había salvado de «disparatadas reformas y de demagógicos intentos de disolución", y que no necesitaba una «reforma que amengüe su fuerte autoridad», sino que eran las masas las que debían ser educadas en el respeto de este principio y el poder público el que tenía que «robustecer, en lugar de debilitar, la acción de sus agentes» ${ }^{46}$.

Mientras tanto, la conspiración militar iniciada poco después de las elecciones seguía su curso. La mayoría de historiadores han coincidido con Julio Aróstegui en la «negligencia, torpeza y pasividad» con las que Casares le

45 «El caso del Cuerpo de Seguridad y Asalto ante la Comisión interministerial», ;Presente...!, 1-7-1936, p. 6; «La Comisión interministerial para la reorganización burocrática», Investigación, 9-7-1936, p. 4; Gaceta de Madrid, 25-6-1936, 177, pp. 2657-2658, y «Los permisos de verano", jPresente...!, 15-7-1936, p. 14.

46 "Carta de mi amigo", jPresente...!, 1-7-1936, p. 13; "Republicanización», Investigación, 19-7-1936, pp. 2-3; "La autoridad y sus agentes», Policía Gubernativa, 15-71936, p. 15, y «El Instituto de la Guardia Civil», ;Presente...! 1-7-1936, pp. 3-4. 
hizo frente. Según esta lectura, dicha actitud se materializó en el menosprecio de las informaciones remitidas por sus subordinados y los socialistas, que se debió tanto al exitoso precedente de la Sanjurjada como a su miedo a la revolución. Sin embargo, como indica Emilio Grandío, no hay ninguna prueba efectiva de la desidia de Casares. Además, resulta extrańo que decidiera arriesgarse a repetir lo sucedido en agosto de 1932 considerando que el malestar en las corporaciones coercitivas le había obligado a frenar su republicanización. En realidad, el Gobierno a finales de febrero había destinado a la periferia a los generales Franco, Goded y Mola y, además, llevaba meses vigilando ciertos cuarteles y trasladando a los jefes de las fuerzas de seguridad que le infundían sospechas. Asimismo, el 3 de junio Alonso Mallol encabezó una inspección en Pamplona para coger in fraganti a Mola, pero una filtración de Santiago Martín Báguenas frustró dicha iniciativa. En último lugar, Casares intensificó la vigilancia en los cuerpos policiales nombrado subdirector general de Seguridad a Carlos de Juan Rodríguez, un fiscal que precisamente había sido designado para investigar las responsabilidades de las fuerzas estatales en Asturias ${ }^{47}$.

Finalmente, el 12 de julio fue asesinado el teniente de Asalto e instructor de las milicias socialistas José del Castillo. Esto provocó un motín policial que forzó a Moles a autorizar la detención de multitud de derechistas. Uno de esos grupos dirigido por Fernando Condés — que había sido amnistiado por su participación en la revolución de octubre y readmitido en la Benemérita como capitán- y formado por guardias de Asalto y miembros del grupo prietista «La Motorizada», detuvo ilegalmente a Calvo Sotelo y, en la misma camioneta, el pistolero Luis Cuenca lo mató de dos disparos en la nuca. Consciente de la gravedad del suceso, el Gobierno concentró los efectivos policiales en Madrid, acuarteló a las tropas y prorrogó el estado de alarma. Esto último fue aprobado en una tensa reunión de la Diputación Permanente en la que Gil Robles leyó su último listado de desórdenes. El diputado responsabilizó a Casares del magnicidio por haber empleado una retórica beligerante y haber permitido una "política de persecución, de exterminio y de violencia» contra las derechas; y advirtió que «cuanto mayor sea la violencia, mayor será la reacción; por cada uno de los muertos, surgirá otro combatiente». No obstante, pese a las medidas del Ejecutivo, la sublevación acabó estallando en el protectorado marroquí el día 17 , provocando el comienzo de una larga y cruenta guerra civil ${ }^{48}$.

47 Martín Ramos (2015): 199; Aróstegui (2006): 96-97 y 161; Alía Miranda (2011): 130; Grandío (2011): 154 y 170; Gaceta de Madrid, 1-7-1936, 183, p. 8, y «La subdirección de Seguridad», Policía Española, 16-7-1936, p. 7.

48 González Calleja (2014): 311-317; AHN, Causa General, Leg. 1560, Exps. 23 y 30; AHN, Causa General, Leg. 1500, Exp. 4; Gaceta de Madrid, 2-7-1936, 184, p. 50; 


\section{CONCLUSIÓN}

El restablecimiento de una política de orden público reformista, civilista y menos represiva respecto a la movilización izquierdista, semejante a la del primer bienio, potenció cuatro catalizadores de la violencia política. Primero, en una estructura de oportunidades caracterizada por la radicalización simultánea del PSOE y la CEDA, la inconsistencia de esta política generó un aumento sustancial del coste político tanto de reprimir como de no reprimir que socavó la legitimidad gubernamental y la cooperación del resto de actores políticos. Segundo, la republicanización de los cuerpos policiales causó una reacción entre su personal que incrementó su politización, lo que profundizó sus divisiones internas, entorpeció la coordinación institucional y resquebrajó su lealtad, tal y como demostraron la participación de numerosos funcionarios en la conspiración y las extralimitaciones de las guardias municipales socialistas. Tercero, el acuartelamiento de la fuerza pública durante las protestas de los simpatizantes del Frente Popular motivó su desautorización, tanto por no intervenir cuando había disturbios como por hacerlo tardíamente de manera desproporcionada. Este problema se agravó debido a la falta de armamento no letal y de adiestramiento en técnicas incruentas de control de multitudes, al aumento de las víctimas mortales entre los agentes y a su creciente animadversión respecto a las organizaciones obreras. Por último, el incremento de la frecuencia de los episodios violentos, el resquebrajamiento del monopolio estatal de la coerción y el protagonismo asumido por el pistolerismo durante esta etapa impulsaron la privatización del ejercicio de la violencia política, lo que a su vez estimuló el miedo de la ciudadanía y facilitó la posterior dramatización de los sucesos.

Casares Quiroga intentó corregir esta deriva sin renunciar a las reformas. Esta nueva política consistía en asumir un discurso antifascista que le permitiera recuperar la confianza de las asociaciones frentepopulistas, frenar la depuración policial y satisfacer algunas de sus aspiraciones profesionales. Su propósito era garantizar su obediencia, restablecer el principio de autoridad actuando más enérgicamente contra las protestas obreras transgresoras y contener la privatización del empleo de la fuerza intensificando la persecución del terrorismo falangista y recobrando el control de los resortes de orden público. Sin embargo, estas disposiciones no tuvieron tiempo suficiente para dar resultados. En realidad, aunque lograron reducir significativamente la tasa diaria de muertes, este indicador continuó estando muy por encima de la media del

Gaceta de Madrid, 4-7-1936, 186, p. 124; Sesiones de la Diputación Permanente de Cortes, 15-7-1936, 5, pp. 6 y 9-10, y Martínez Barrio (1983): 345-354. 
periodo republicano. Además, esta estrategia no reportó al Gobierno los apoyos sociopolíticos que pretendía, ni tampoco bastó para contener la politización de las instituciones coercitivas ni para restablecer la hegemonía estatal sobre el uso letal de la represión.

La complejidad del vínculo entre las políticas de orden público y la violencia política del Frente Popular hace precisa una explicación que tenga en cuenta, como mínimo, estos cuatro factores y que no se limite a condenar la lenidad o la intransigencia de las autoridades. En realidad, el problema residió en su falta de habilidad para combinar la represión con la tolerancia de manera proporcionada a la peligrosidad de las diferentes protestas, manteniendo los apoyos políticos necesarios para gobernar. Asimismo, partiendo de este enfoque, el respaldo a la sublevación de al menos la mitad de las fuerzas policiales adquiere más sentido como una reacción no solo contra la incapacidad del Gobierno para restablecer el orden, sino también contra unas reformas democratizadoras que — desde su punto de vista— solo habían servido para socavar su autoridad y resquebrajar aquello cuyo ejercicio constituía su razón de ser: el monopolio estatal de la violencia.

\section{Bibliografía}

Alía Miranda, F. (2011). Julio de 1936. Conspiración y alzamiento contra la Segunda República. Barcelona: Crítica.

Álvarez Tardío, M. y Villa García, R. (2010). El precio de la exclusión. La política durante la Segunda República. Madrid: Encuentro.

- (2013). El impacto de la violencia anticlerical en la primavera de 1936 y la respuesta de las autoridades. Hispania Sacra, 132, 683-764. Disponible en: https://doi.org/10.3989/ hs. 2013.033.

Aróstegui, J. (2006). Por qué el 18 de julio... Y después. Barcelona: Flor del Viento Ediciones. Arrarás, J. (1968). Historia de la Segunda República española (4 vols.). Madrid: Editora Nacional. Azaña, M. (2004). Diarios completos. Monarquía, República, Guerra Civil. Barcelona: Crítica. Blaney, G. (2007). Keeping Order in Republican Spain, 1931-1936. En G. Blaney (ed.). Policing Interwar Europe. Continuity, Change and Crisis, 1918-1940 (pp. 31-68). Basingstoke: Cañada Blanch Centre for Contemporary Spanish Studies-Palgrave Macmillan.

— (2012). En defensa de la democracia: políticas de orden público en la Espańa republicana, 1931-1936. Ayer, 88, 99-123.

Casanova, J. (2007). República y guerra civil. En J. Fontana y R. Villares (dirs.). Historia de España (vol. 8). Barcelona: Marcial Pons.

Cierva, R. (1967). Los documentos de la primavera trágica. Análisis documental de los antecedentes inmediatos del 18 de julio de 1936. Madrid: Secretaría General Técnica.

Cruz, R. (2006). En el nombre del pueblo. República, rebelión y guerra en la España de 1936. Madrid: Siglo Xxi. 
Del Rey, F. (2007). Reflexiones sobre la violencia política en la II República española. En M. Gutiérrez Sánchez y D. Palacios Cerezales (eds.). Conflicto politico, democracia y dictadura. Portugal y España en la década de 1930 (pp. 17-96). Madrid: Centro de Estudios Políticos y Constitucionales.

- (2008). Paisanos en lucha. Exclusión política y violencia en la Segunda República espanola. Madrid: Biblioteca Nueva.

— Repertorios. La politica de enfrentamiento en el siglo XX. Madrid: Centro de Investigaciones Sociológicas.

Estado español (1939). Dictamen de la Comisión sobre ilegitimidad de poderes actuantes en 18 de julio de 1936. Madrid: Editora Nacional.

Gil Andrés, C. (2000). Echarse a la calle. Amotinados, huelguistas y revolucionarios (La Rioja, 1890-1936). Zaragoza: Prensas Universitarias de Zaragoza.

Gil Robles, J. M. (2006). No fue posible la paz. Barcelona: Ariel.

González Calleja, E. (2014). En nombre de la autoridad. La defensa del orden público durante la Segunda República española (1931-1936). Granada: Comares.

- (2015). Cifras cruentas. Las víctimas mortales de la violencia sociopolitica en la Segunda República española (1931-1936). Granada: Comares.

Grandío, E. (2011). Casares y el 18 de julio. En E. Grandío y J. Rodero (eds.). Santiago Casares Quiroga. La forja de un lider (pp. 153-195). Madrid: Editorial Eneida.

Jackson, G. (2005). La República española y la Guerra Civil. Madrid: RBA.

Ledesma, J. L. (2013). La "primavera trágica» de 1936 y la pendiente hacia la guerra civil. En F. Sánchez Pérez (coord.). Los mitos del 18 de julio (pp. 313-339). Barcelona: Crítica.

Martín Ramos, J. L. (2015). El Frente Popular. Victoria y derrota de la democracia en España. Barcelona: Pasado y Presente.

Martínez Barrio, D. (1983). Memorias. Barcelona: Planeta.

McAdam, D. (1999). Orígenes terminológicos, problemas actuales y futuras líneas de investigación. En D. McAdam, J. D. McCarthy y M. Zald (eds.). Movimientos sociales: perspectivas comparadas. Oportunidades políticas, estructuras de movilización y marcos interpretativos culturales (pp. 49-70). Madrid: Istmo.

Mera Costas, P. (2015). Monárquico, republicano, liberal. Biografía política de Manuel Portela Valladares [tesis doctoral]. Universidad Complutense de Madrid. Disponible en: https://bit.ly/2UTyd57.

Palacios Cerezales, D. (2011a). Ansias de normalidad. La policía y la República. En F. del Rey (ed.). Palabras como puños. La intransigencia politica en la Segunda República española (pp. 596-646). Madrid: Tecnos.

(2011b). Sin efusión de sangre: protesta, policía y costes de la represión. En M. J. Funes (ed.). A propósito de Tilly. Conflicto, poder y acción colectiva (pp. 247-264). Madrid: Centro de Investigaciones Sociológicas.

Payne, S. G. (2016). El camino al 18 de julio. La erosión de la democracia en España (diciembre de 1935-julio de 1936). Barcelona: Espasa.

Portela Valladares, M. (1988). Memorias. Dentro del drama español. Madrid: Alianza Editorial.

Prada Rodríguez, J. (2011). Violencia política y protesta social durante la primavera trágica. Su contribución a la estrategia del «cuanto peor, mejor». En E. González Calleja y R. 
Navarro Comas (eds.). La España del Frente Popular. Política, sociedad, conflicto y cultura en la España de 1936 (pp. 121-136). Granada: Comares.

Ranzato, G. (2008). El peso de la violencia en los orígenes de la guerra civil de 1936-1939. Espacio, Tiempo y Forma. Serie V, Historia Contemporánea, 20, 159-182.

Requena Gallego, M. (1983). Los sucesos de Yeste (mayo 1936). Albacete: Instituto de Estudios Albacetenses.

Rivas, F. (1976). El Frente Popular: (antecedentes de un alzamiento). Madrid: Editorial San Martín.

Rivas Cherif, C. (1979). Retrato de un desconocido. Vida de Manuel Azaña. Barcelona: Ediciones Grijalbo.

Sánchez Pérez, F. (2016). Movilización sociolaboral y oportunidades políticas en España y Francia durante la primavera de 1936. Nuestra Historia, 1, 24-47.

Tarrow, S. (1997). El poder en movimiento. Los movimientos sociales, la acción colectiva y la politica. Madrid: Alianza Editorial.

Vidarte, J. S. (1973). Todos fuimos culpables. Testimonio de un socialista español. México D. F.: Fondo de Cultura Económica. 